Dinamika Sosial Budaya, Vol 22, No. 2, Desember 2020, pp 166-173

p-ISSN: 1410-9859\& e-ISSN: 2580-8524

http://journals.usm.ac.id/index.php/jdsb

\title{
Kurangnya Kesadaran Masyarakat Dalam Beradaptasi Sosial Di Pandemi Covid 19 (Studi kasus desa Rantau Durian II kecamatan Lempuing Jaya kabupaten Ogan Komering Ilir provinsi Sumatera Selatan )
}

Cindy Irawan

Jurusan sosiologi fakultas ilmu sosial dan politik universitas sriwijaya

Corresponding author: cindyirawan00@gmail.com

\begin{abstract}
Abstrak
Penelitian ini yaitu peradaban bergeser ke situasi yang tidak menentu. Hal ini disebabkan publik dan kewenangan negara harus takluk standar protokol kesehatan. Masa adaptasi ini tentunya mengubah perilaku masyarakat, apakah itu di dunia pendidikan, pembelajaran agama/dakwah (Sainuddin, 2020). Penelitian sebelum ini mempunyai sedikit persamaan Studi ini mengkaji tentang kurangnya adaptasi dan kesadaran masyarakat desa Rantau durian II dalam masa pandemi covid-19. Tujuan studi ini adalah untuk motivasi para masyarakat desa rantau durian II dalam kesadaran dan beradaptasi pada massa pandemi covid-19,mengapa sebagian masyarakat memunculkan perilaku tersebut, dan bagaimana cara mengatasinya. Proses pengumpulan data dilakukan dengan cara mewawancarai masyarakat dan peneliti mengamati langsung masyarakat desa rantau durian II, Materi hasil interview dan pengamatan yang diperoleh ditranskrip dan dianalisis menunjukkan bahwa perilaku yang ditampilkan oleh orang-orang yang tidak mematuhi himbauan pemerintah. Metode penelitian yang digunakan dalam penelitian ini adalah studi literatur dengan pendekatan analisis deskriptif. Hasilnya Hasil analisis memunculkan tema yang dibahas di sini: dukungan sosial, kesejahteraan jiwa, pengaruh media dan tujuan adaptasi. Kajian tentang tema tersebut sangat berguna untuk memahami bagaimana cara optimal meningkatkan motivasi dan kesadaran masyarakat rantau durian II.
\end{abstract}

\begin{abstract}
This research is civilization shifting to an uncertain situation. This is because the public and state authorities must be subject to standard health protocols. This adaptation period certainly changed people's behavior, whether it was in the world of education, religious learning /da'wah (Sainuddin, 2020). Previous research has little in common This study examines the lack of adaptation and awareness of the villagers of Rantau durian II during the covid-19 pandemic. The purpose of this study is to motivate the villagers of durian II region in awareness and adapt to the mass of covid19 pandemic, why some people bring up the behavior, and how to overcome it. The data collection process is conducted by interviewing the community and researchers observe directly the villagers of durian II region, The material of the interview results and observations obtained is transcribed and analyzed shows that the behavior displayed by people who do not comply with the government's appeal. The research method used in this research is literature study with a descriptive analysis approach. The results The results of the analysis bring up the themes discussed here: social support, mental well-being, media influence and adaptation goals. The study of this theme is very useful for understanding how to optimally increase the motivation and awareness of the Rantau durian II communit
\end{abstract}

Keywords: covid-19, awareness, social adaptation, motivation, community role, mental wellbeing 
Dinamika Sosial Budaya, Vol 22, No. 2, Desember 2020, pp 166-173

p-ISSN: 1410-9859\& e-ISSN: 2580-8524

http://journals.usm.ac.id/index.php/jdsb

\section{PENDAHULUAN}

Coronavirus (COVID-19) adalah penyakit menular yang disebabkan oleh coronavirus versi baru yang ditemukan pada akhir 2019 lalu, virus baru ditemukan setelah wabah ini meradang di kota Wuhan, Tiongkok, bulan Desember 2019. COVID-19 ini sekarang menjadi sebuah pandemi yang terjadi di banyak negara di seluruh dunia di indonesia sendiri menjadi permasalahan yang cukup besar, sebagian besar gangguan yang dialami oleh individu yang terinfeksi virus COVID-19 akan mengalami penyakit pernapasan ringan hingga sedang dan sembuh tanpa memerlukan perawatan khusus. Ada setidaknya dua gejala berat seperti Middle East RespiratorySyndrome (MERS) dan Severe Acute Respiratory Syndrome (SARS). Hal baru Coronavirus Diseases 2019 (COVID-19) belum pernah diidentifikasi sebelumnya pada manusia. Tanda dan gelaja umum infeksi COVID-19 antara lain gejala gangguan pernapasan akut seperti demam, batuk, dan sesak napas. Masa inkubasi rata-rata 5-6 hari dengan masa inkubasi terpanjang 14 hari. Prosentase penularannya lebih cenderung pada individu usia lanjut dan mereka yang memiliki riwayat masalah kesehatan yang rentan seperti kardiovaskular, diabetes, penyakit pernapasan kronis, dan kanker di mana lebih cenderung mempermudah pengembangan infeksi virus COVID-19 menjadi penyakit yang lebih serius. pandemi yang terjadi di seluruh dunia menciptakan situasi anomali di segala bidang, baik itu di dunia pendidikan, ekonomi politik, sosialbudaya, sampai di kehidupan religius, begitu pula dalam konstruksi infrastruktur (Arsyam, 2020). (Yurianto, Ahmad, 2020) Penyebaran virus corona ini pada awalnya sangat berdampak pada dunia ekonomi yang menurun, tetapi kini dampaknya dirasakan juga masyarakat secara luas. Kebijakan yang diambil oleh banyak negara termasuk
Indonesia dengan bebagai cara, membuat pemerintah dan lembaga terkait harus menghadirkan alternatif proses penyelesaian. Aktivitas yang melibatkan kumpulan orang-orang kini mulai dibatasi. Pemerintah sudah mengimbau untuk bekerja, belajar, dan beribadah dari rumah untuk menekan angka pasien yang terpapar COVID-19.

Peradaban bergeser ke situasi yang tidak menentu. Hal ini disebabkan publik dan kewenangan negara harus menyusun strategi new normal dan menyiapkan segala fasilitas dan perlindungan masyarakat pada standar protokol kesehatan. Masa adaptasi ini tentunya mengubah perilaku masyarakat, apakah itu di dunia pendidikan, pembelajaran agama/dakwah (Sainuddin, 2020) sampai di arena kebudayaan, bahkan dalam strategi penulisan skripsi (Wekke, 2020). Namun, tidak dapat dipungkiri keberadaan pandemi ini ternyata mendapatkan respon yang beragam di tengah masyarakat dunia. Angka pasien COVID 19 di seluruh dunia telah mencapai angka 17, 9 juta jiwa dengan jumlah kematian mencapai 685 ribu jiwa, namun masih saja ada (kelompok) masyarakat yang menganggap pandemi COVID 19 sebagai intrik politik dan konspirasi. Terutama di media sosial, dakwah dan edukasi dianggap memberikan pandangan yang paradoks. Di satu sisi informasi menjadi begitu terbuka, di sisi lain informasi keliru pun juga ikut merebak (Sainuddin, 2020). Oleh karenanya, dibutuhkan formulasi tertentu agar masyarakat percaya bahaya wabah ini.

Peran masyarakat sangat penting dalam kondisi seperti ini, sebelumnya masyarakat dapat beraktivitas dengan leluasa diluar rumah sedangkan sekarang hanya dapat berdiam dirumah saja, Peran masyarakat memiliki artian tindakan yang dilakukan oleh sekelompok orang yang 
mencerminkan kesamaan perilaku sebagai sebuah entitas komunal yang berkaitan dengan struktur sosial tertentu. Peran masyarakat sangatlah besar di pandemi covid-19 peran berhubungan perilaku tapi secara luasnya masyarakat dituntut/diharuskan mematuhi demi mencapai kesamaan perilaku untuk mencapai struktur yang di harapkan mencegah bersama menularnya Covid-19 membuat dunia menjadi resah.disini diperlukannya kesejahteraan jiwa keadaan yang menyebabkan masyarakat merasa aman santosa, makmur, dan selamat serta terlepas dari segala macam gangguan dan kesukaran karena semakin meluasnya wabah dan dampak dari virus ini secara signifikan didalam segi-segi kehidupan masyarakat Indonesia maka menjaga kesehatan mental tetap dalam kondisi prima adalah suatu keharusan. Mental yang sehat akan membuat kepuasaan hidup yang erat kaitannya dengan kebahagiaan dimana orang yang bahagia akan memiliki sistem imun yang tinggi sehingga dapat menangkal wabah virus, bagaimana kiat kita menjaga kesejahteraan jiwa atau kesehatan mental. konsep penting dalam menjaga kesejahteraan jiwa adalah spiritualitas. spiritualitas adalah bagaimana seseorang memandang kehidupannya memiliki koherensi dan bertujuan, namun juga memperoleh pengalaman personal melalui kekuatan yang dia yakini sebagai suatu yang melingkupi, mendasari atau melampaui kehidupan, serta sebagai pencarian terhadap Yang Maha Suci sebagai aspek non material dari religiusitas. Menggunakan spiritualitas sebagai mekanisme koping melalui masa-masa sulit yang intens berkorelasi dengan tingkat harapan yang lebih tinggi, optimisme, dan hasil kehidupan yang positif. Oleh karena itu banyak bertafakur dirumah sesuai kepercayaan masyarakat seperti berdoa, dan beribadah dengan konsentrasi penuh, dan meditasi merupakan salah satu hal terbaik untuk dapat menjaga kejiwaan kita berada dalam kondisi yang stabil. Kesejahteraan jiwa suatu harapan keluar dari permasalahan wabah ini yang dimulai dari pemikiran pemahaman dalam individu dan faktor faktor internal dan eksternal.

Terhitung sejak awal Januari 2020, dunia mengalami pandemi hebat yang disebut Corona Virus Diseases 2019 (COVID-19) (Albana,2020). Pada konteks sekarang, kesadaran sebagai bagian dari masyarakat yang saling mendukung, kesadaran sebagai warga negara sangat dibutuhkan sebagai rasa sadar yang muncul dari hati dan pikiran masyarakat untuk bersikap dan melakukan sebuah tindakan (Arditama \& Lestari, 2020). Kesadaran (Consciousness) adalah kesiagaan (awareness) seseorang terhadap peristiwaperistiwa di lingkungannya (seperti pemandangan dan suara-suara dari lingkungan sekitarnya) serta peristiwaperistiwa kognitif yang meliputi memori, pikiran, perasaan, dan sensasi-sensasi fisik. Dalam hal ini kesadaran memiliki dua sisi yaitu kesadaran yang meliputi pemahaman terhadap stimuli lingkungan sekitar dan pengenalan seseorang akan peristiwaperistiwa mentalnya sendiri seperti pikiranpikiran yang ditimbulkan oleh memori dan oleh kesadaran pribadi akan jati dirinya. Dimana timbulnya kesadaran dalam diri sendiri perlu di munculkan dalam menghadapi pandemi ini dimulai dari pemikiran pemikiran, perasaan tiap individu seperti motivasi Berdasarkan pada kata dasarnya - motif, motivasi yang ada pada seseorang merupakan pribadi seseorang yang mendorong keinginan individu untuk melakukan kegiatan - kegiatan tertentu guna mencapai tujuannya. tujuan dalam masyarakat pada saat pandemi ini untuk menurunkan penularan kasus covid-19 di indonesia motivasi pendorong individu inilah 
yg akan membuat penurunan kasus ini mau tidak mau harus membuat perubahanperubahan yang mengakibatkan seseorang dalam suatu kelompok sosial dapat hidup dan berfungsi lebih baik dalam lingkungannya. Pada saat pandemi ini adaptasi sosial harus di sesuaikan dengan keadaan pandemi contoh nya saja budaya jabat tangan/salaman, menggunakan protokol kesehatan dari pemerintah dan menjaga jarak. Meskipun banyak faktor yang mempengaruhi perilaku yang berhubungan dengan kesehatan, kesadaran akan risiko untuk membuat perubahan perilaku masyarakat adalah unsur utama untuk meningkatkan kesehatan individu dan status kesehatan masyarakat agar terhindar dari COVID-19 (Sampurno et al., 2020). Social distancing is recommended for all ages to slow the spread of the virus, protect the health care system, and help protect vulnerable older adults" yang diartikan dalam bahasa Indonesia Jarak sosial direkomendasikan untuk semua umur untuk memperlambat penyebaran virus, melindungi sistem perawatan kesehatan, dan membantu melindungi orang dewasa yang rentan (Morbidity and Mortality Weekly Report, 2020). Permasalahan ini didukung oleh beberapa riset di seluruh dunia dalam memprediksi puncak sebaran COVID-19 yang beberapa negara sudah masuk dalam masa lonjakan kedua. Untuk wilayah Indonesia beberapa peneliti menggunakan pendekatan soft computing, seperti Support Vector Machine (SVM) regression, dengan beberapa kernel pilihan, antara lain radial basis function, linear and polynomial dengan akurasi yang beragam. Alat bantu dari Google (Google Interactive Notebook) sangat membantu dengan fasilitas kompiler dan servernya (Herlawati, 2020).

Tujuan studi ini adalah untuk motivasi para masyarakat desa rantau durian II dalam kesadaran dan beradaptasi pada massa pandemi covid-19, untuk mengetahui mengapa sebagian masyarakat memunculkan perilaku tersebut, dan bagaimana cara mengatasinya dengan edukasi masyarakat terhadap COVID-19 melalui media sosial dan budaya yang ada di dalamnya. Lebih lanjut, penelitian ini turut mengidentifikasi bagaimana media mempengaruhi masyarakat dan dengan melibatkan komunikasi media massa dalam strategi untuk meningkatkan kesadaran tentang usaha penanganan dan pencegahan COVID-19. Tanpa kita ketahui kapan berakhirnya Pandemi COVID-19 belum ada yang mampu memprediksinya secara akurat. Makin lama pandemi berada di sekitar kita, apalagi bila terjadi peningkatan dalam kasus dan pembatasan dalam kehidupan berinteraksi. Karena itu, kesadaran bagi seluruh warga sepanjang tahun di mana pun bermukim sangat di butuhkan di desa maupun kota, perlu tetap diupayakan kerjasama antara pemerintah bersama masyarakat. sebuah langkah kecil dalam mewujudkan pencegahan penyebaran apabila dilakukan secara masif di setiap rumah tangga perkotaan dengan dukungan dari pemerintah sedikit banyak akan membantu mewujudkan penurunan dan pencegahan pemularan pada masa pandemi COVID-19 ini. Sudah seharusnya kemandirian dimulai dari individu, rumah tangga sebagai unit terkecil kemudian satu RT (rukun tetangga), diikuti satu RW (rukun warga) dan selanjutnya satu desa/ kelurahan hingga sampai tingkat nasional

\section{METODE}

Metode penelitian yang digunakan dalam penelitian ini adalah studi literatur dengan metodelogi pendekatan analisis deskriptif. pentingnya masyarakat Rantau Durian 2 yang perlu memahami kesadaran dan motivasi sehingga mengamati dengan data apa yang di temukan di lapanagan dengan cara mendeskripsikan data dan fakta 
melalui kata-kata secara menyeluruh terhadap subjek penelitian, di kumpulkan Data dalam penelitian ini menggunakan teknik pengamatan: Sebuah. Observasi Partisipatif aktif Dalam observasi ini, peneliti terlibat dengan kegiatan sehar-hari orang yang sedang diamat atau yang digunakan sebagai sumber data penelitian. Dengan observasi partisipan ini, maka data yang diperoleh akan lebih lengkap, tajam, dan sampai selamat pada tingkat makna dari setiap perilaku yang nampak dan dengan begitu proses komunikasi dengan mewawancarai masyarakat dan peneliti mengamati langsung masyarakat desa rantau durian II, Materi hasil interview dan pengamatan yang diperoleh ditranskrip dan dianalisis menunjukkan bahwa perilaku yang ditampilkan oleh orang-orang yang tidak mematuhi himbauan pemerintah. Hasil analisis memunculkan tema yang dibahas di sini: dukungan sosial dalam kesejahteraan, pengaruh media dan hambatan adaptasi. Kajian tentang tema tersebut sangat berguna untuk memahami bagaimana cara optimal meningkatkan motivasi dan kesadaran masyarakat rantau durian II.

\section{HASIL DAN PEMBAHASAN Hasil penelitian}

\section{Dukungan sosial yang perlu masyarakat patuhi selama pandemi}

Berdasarkan hasil wawancara pada perangkat desa dan masyarakat-masyarakat rantau durian 2, banyak dukungan sosial yang muncul pada masa pandemi ini baik dari pemerintah maupun masyarakat seperti pembagian bantuan langsung tunai(BLT), bantuan untuk UKMK, pembagian masker dari desa, membuat post siaga covid-19, Aparat pemerintah desa menghimbau sekolah dan acara acara tahunan di desa di tiadakan sementara demi kesejahteraan bersama, dan masyarakat yang menggunakan masker saat beraktifitas di luar rumah, penerapan sosial distancing, dan selalu menjaga kebersihan lingkungan sekitar. Bisa dilihat dari antusias masyarakat dalam lebih menjaga kebersihan di setiap depan rumah di sediakanya tempat mencuci tangan, kecendrungan menjaga pola hidup sehat juga terlihat dari dukungan masyarakat rantau durian 2 seperti memulai membuat jamu jamuan herbal untuk memperkuat imun tubuh dan lebih memfokuskan dalam berkerja atau rumah tempat tinggal di banding berkerumun.

\section{Pengaruh media massa}

Masyarakat rantau durian 2 di beri informasi berbagai macam media seperti televisi, radio, surat kabar, majalah, buku, dan film. Di desa rantau durian 2 penyebaran informasi dengan mudah di dapat dari televisi berdasarkan hasil wawancara dari 10 masyarakat dan menyebar angket di masyarakat dari sini dapat disimpilkan masyarakat menyempatkan waktu dalam sehari untuk menonton tv selama dua jam. Marshal Mc Luhan yang merupakan ahli teori media, melihat khalayak pada titik pusat berbagai serangan yang dilakukan oleh berbagai media masa. implosi media yang memberikn infirmasi yang ringan tetapi membuat seseorang terpengaruh pola pokir, pemahaman, dan berperilaku pada masyarakat bisa negative maupun positif seperti penyebaran informasi dari media massa pengaruh yang terjadi dapat berupa pengaruh opini, persepsi khalayak, penyerapan informasi, bahkan paradigma dan perilaku masyarakat rantau durian 2 .

Hambatan-Hambatan masyarakat dan Pemberian Penguatan Saat Masa Pandemi Covid-19

Berdasarkan hasil wawancara dan mengamati dalam masyarakat, dijelaskan bahwa hambatan-hambatan yang ditemui 
Dinamika Sosial Budaya, Vol 22, No. 2, Desember 2020, pp 166-173

p-ISSN: 1410-9859\& e-ISSN: 2580-8524

http://journals.usm.ac.id/index.php/jdsb

oleh masyarakat dalam pemberian penguatan pada masyarakat masa pandemi COVID-19 adalah terdapat beberapa orang tua yang menuntut tinggi tradisi dan kesopanan atau yang kurang bisa menerima perubahan sosial dalam masa pandemi seperti masih adanya sistem jabat tangan berkerumun tanpa memiliki batas yang telah di anjurkan pemerintah Sehingga pemberian penguatan tidak bisa dengan cepat dilakukan, ada pula orang orang yang tidak mau tahu dan menganggap itu hal yang sepele beranggapan masyarakat desa tidak akan pernah di masuki virus COVID-19 karena mayoritas masyarakat desa rantau durian 2 adalah menetap tempat tinggal dan jarang sekali keluar daerah.

Selain itu juga terdapat beberapa orang yang kesulitan dalam pendapatan sehingga untuk membeli pemenuhan anak dalam belajar online, antiseptic keperluan kebersihan dan perlindungan diri. akses sinyal dan informasi daerah desa rantau durian 2 yang cukup jauh membuat lokasi tidak mudah dijangkau oleh sinyal. Sehingga komunikasi yang dilakukan oleh masyarakat menjadi terhambat masyarakat juga tidak mudah memahami apa yang sedang terjadi di dunia sekarang.

Di dalam penguatan ini terdapat 2 jenis yaitu :

1. Penguatan verbal adalah sebuah partisipasi masyarakat dalam menggunkana masker, dan saling mengingatkan apabila melihat seseorang tanpa masker, saling berbagi pengetahuan perkembangan covid-19 tanpa kepanikan dan memberi dukungan setiap masyarakat untuk menjalani hari hari di masa pandemi.

2. Penguatan Non-verbal, seperti tingkah laku masyarakat dalam bersosial di tempat tinggal menjaga jarak sesuai protokol kesehatan.

\section{PEMBAHASAN}

Penulisan ini menunjukkan penelitian hal-hal penting dari dampak wabah terhadap kondisi sosial masyarakat terkait virus corona. Kemajuan yang signifikan diamati dalam penelitian sebelumnya yang terkait dengan virologi, epidemiologi, penyakit menular, dan lain-lain. Namun, dalam penelitian yang terkait dengan kesehatan masyarakat, tata kelola, teknologi, dan komunikasi risiko tampaknya ada area kesenjangan. Meskipun peta jalan penelitian global Organisasi Kesehatan Dunia (WHO) telah mengidentifikasi penelitian terkait ilmu sosial sebagai bidang prioritas, lebih banyak fokus perlu diberikan di hari-hari mendatang untuk penelitian multi, lintas, dan lintas disiplin terkait kesehatan masyarakat dan risiko bencana serta pemahaman dalam kelompok berskala kecil dalam Masyarakat tujuan adaptasi desa.

Objek penelitian ini kurangnya kesadaran beradaptasi pada motivasi masyarakat terkait covid-19 mulanya masyarakat desa harus berfikir apa yang perlu diketahui di masa pandemi ini seperti :

\section{Hoaks Dan Misinformasi COVID-19 Berdampak Mengerikan}

Berita hoaks tidak boleh di acuhkan pada masa pandemic seperti ini karena dapat membuat kebingungan, kecemasan,hingga kematian. Sebagai masyarakat yang mendapat informasi perlu adanya penyaringan dalam berfikir dengan mencari tau kebenaran lewat internet media informasi yang telah ada agar terhindar dari hoaks yang tersebar luaskan. Permasalahan covid di desa rantau durian sering sekali simpang siur dan terkesan menakut nakuti masyarakat desa hal 
Dinamika Sosial Budaya, Vol 22, No. 2, Desember 2020, pp 166-173

p-ISSN: 1410-9859\& e-ISSN: 2580-8524

http://journals.usm.ac.id/index.php/jdsb

inilah yang membuat penelitian ini diperlukan di desa rantau durian 2 perangkat desa sudah sangat menghimbau masyarakat agar menyaring informasi yang di dapat dengan adanya arahan dari polsek lempuing jaya yang langsung memberi arahan terpidana apabila seseorang menyabar luaskan hoaks.

\section{Adaptasi Kebiasaan Baru Selama Pandemi}

Upaya pemahaman pada masyarakat desa diperlukan seperti cara pencegahan dan penyadaran melalui contohnya sosialisasi karena banyak masyarakat menyepelekan penggunaan masker, handsanitaizer dan mencuci tangan, penyadaran pengecekan suhu dan wajib menggunakan masker tubuh saat ingin memasuki pasar, dan aara acara yang melibatkan bnyak orang di wajibkan menggunakan masker serta patuhi arahan pemerintah setempat dan menjaga imun tubuh.

1. Selalu gunakan masker saat keluar rumah. Kenapa? Karena kita mungkin membawa virus tapi tidak memiliki gejala atau hanya gejala ringan, sehingga bisa menularkan ke orang lain. Tapi masker harus dipakai dengan benar! Pastikan masker menutupi hidung, mulut, dan dagu dan hanya dipakai satu kali! Masker kain dipakai ulang setelah dicuci dengan deterjen. tetapi masker medis harus dibuang begitu sampai di rumah.

2. Hindari menyentuh mata, hidung, dan mulut. Saat menyentuh benda-benda yang sering disentuh orang lain seperti pegangan pintu, uang, meja makan, tangan Anda bisa terpapar virus. Mata, hidung, dan mulut merupakan pintu masuk virus.
3. Selalu ambil jarak lebih dari 1 meter dari orang-orang saat berada di luar rumah. Kadang kita merasa tidak nyaman saat ada yang berdiri terlalu dekat, semisal saat mengantri. Jangan ragu, minta dengan sopan agar mereka menjaga jarak dengan mengatakan "Maaf, tolong jaga jarak, ya".

4. Sering cuci tangan dengan sabun. Kita sudah sering mendengar hal ini. Tapi pastikan kita melakukannya dengan tepat, selama minimal 20 detik dan selalu lakukan saat tiba di rumah atau di tempat tujuan. Saat di luar rumah, cairan pencuci tangan yang mengandung alkohol merupakan pilihan bila sabun dan air mengalir tidak tersedia.

5. Selalu ikuti perkembangan informasi dan hanya ikuti sumber terpercaya seperti situs ini. Setiap kali ada krisis, ada saja orang-orang yang suka menyebarkan informasi palsu dan hoaks yang membingungkan masyarakat dan membuat situasi menjadi lebih buruk.

Stigma Masyarakat. Stigma masyarakat adalah hal penghalang yang membuat pencegahan penyakit ini menjadi merebak dikarenakan cara piker msyarakat itu sendiri yang buat suatu penyakit menjadi mematikan dengan adanya pengucilan antara positif dan negative. Hal ini memerlukan dukungan Bersama baik pemberitaan media masa dan lingkungan hidup sekitar yang menjadikan self positive dalam diri seseorang. 
Dinamika Sosial Budaya, Vol 22, No. 2, Desember 2020, pp 166-173

p-ISSN: 1410-9859\& e-ISSN: 2580-8524

http://journals.usm.ac.id/index.php/jdsb

\section{SIMPULAN}

Penelitian ini ingin mengeksplorasi tentang edukasi masyarakat terhadap COVID-19 melalui media sosial dan budaya yang ada di dalamnya masyarakat cendrung lebih menanggapi media masa sebagai pembentuk pola pikir dengan adanya tekanan untuk mengakses serta waktu yang fleksibel. Lebih lanjut, penelitian ini turut mengidentifikasi bagaimana media mempengaruhi masyarakat dan dengan melibatkan komunikasi media massa dalam strategi untuk meningkatkan kesadaran tentang usaha penanganan dan pencegahan COVID-19 masyarakat rantau durian yang dimana sebagian masih belum menyadari bagaimana pola penyebaran virus, pentingnya menjaga kesehatan dan bagai mana pola masyarakat mendukung keberlangsungan pencegahan.

\section{DAFTAR PUSTAKA}

Wijaya, C. (2020). Siapa saja yang paling rentan terkenal dan sakit parah akibat virus corona?. Diakses pada 25 Mei 2020, dari https://www.bbc.com/indonesia/indonesia$\underline{51411440}$

Zulfitri, Z. (2017). Pengaruh Pemberian Penguatan Terhadap Perkembangan Moral Anak di Kelompok B3 TK Negeri Pembina Palu, Bungamputi, 4(2)

Praherdhiono, H., Adi, E. p., Prihatmoko, Y., Nindigraha, N., Soepriyanto, Y., Indreswari, H., H \& Oktaviani, H.I. (2020). Implementasi Pembelajaran Di Era Dan Pasca Pandemi Covid-19. Seribu Bintang.
Kementrian Kesehatan Republik Indonesia (2020). Kesiapsiagaan Menghadapi Infeksi Novel Coronavirus. Diakses dari https://www.kemenkes.go.id/article/view/20 012900002/Kesiapsiagaan-menghadapaiInfeksi-Novel-Coronavirus.html pada 03 Juni 2020

Raharjo, ST. 2016. PerpektifKekuatan Dalam Pekerjaan Sosial. Jurnal EMPATI: Jurnal Ilmu Kesejahteraan Sosial 5 (1), 1-10. UIN Syarif HidayatullahWorld Health Otganization (2020).

McQuail, Dennis, Teori Komunikasi Massa; McQuali's Mass Communication Theory, Edisi 6, (Jakarta; Salemba Humanika, 2011).

DeVito, A Joseph, Komunikasi Antarmanusia, Ed.Kelima, (New York; Professional Books, 1997).

Bajari, Atwar, dan Sahala Tua Saragih, Komunikasi Kontekstual Teori dan Praktik Kontemporer, Pengantar: Prof. Deddy Mulyana, M.A, P.D, (Bandung; PT. Remaja Rosdakarya, 2011) 
Dinamika Sosial Budaya, Vol 22, No. 2, Desember 2020, pp 166-173 p-ISSN: 1410-9859\& e-ISSN: 2580-8524

http://journals.usm.ac.id/index.php/jdsb 